\title{
Personal Preference in Choosing a Job
}

\author{
Kavya Pradeep, Sreeya B
}

\begin{abstract}
Work preferences are the foundation of job satisfaction generally. People will select or confront enhancements or decreases in essential occupation attributes. Consider the type of working environment you want. Employees who find their job fulfilling are more likely to. Perform better at their job. Pick up new tasks quickly and enthusiastically. Think about the nature of the work, the hours, location, job security, rate of pay, benefits, size, type of organization, and so on. To look for some kind of employment that is the best fit for you, you'll have to comprehend your work inclinations. These preferences will reflect your most important skills, interests, and. values. Individual preference for employments has just been impressively examined in the sociologies amid the most recent decades. Think about the skills you want to use or develop. Consider both your specific skills for work and the skills you can transfer from other parts of your life, such as organization or strength. This research investigates about the personal preference in choosing a job. The research has collected data from 1850 respondents by simple sampling method. The research is a descriptive research. The research tools are independent t test, chi square, and ANOVA. Independent variables are gender, educational qualification, and age respectively. It is concluded that most of young people choose their job through their passion or interests, job security and reasonable salary or pay.
\end{abstract}

Keywords: Preferences, job satisfaction, organization, work environment, security, salary.

\section{INTRODUCTION}

Work preferences are the foundation of job satisfaction and keeping in mind that we could compose an entire exposition on the significance of occupation fulfillment, we'll keep this quick and painless. Employees who find their job fulfilling are more likely to: Perform better at their job. Pick up new tasks quickly and enthusiastically. To look for some kind of employment that is the best fit for you, you'll have to comprehend your work inclinations. These preferences will reflect your most important skills, interests, and. values. Individual preference for employments have just been impressively examined in the sociologies amid the most recent decades. One conceivable issue of this methodology is that socially attractive answers may happen with the goal that genuine inclinations are not uncovered. In some different examinations people are solicited to pick among an assortment from theoretical occupations which vary in some controlled ,talk about this arrangement catching methodology. True choices of representatives are not considered in the lion's share of past examinations. This commitment, accordingly, offers an extra way to deal with investigate work inclinations of representatives dependent on choices on employment change. I break down representatives who change their occupations and whose divisions from their old employments were started without

Revised Manuscript Received on 14, October 2019.

Kavya Pradeep, B.B.A. L.LB. (Hons.), Saveetha School of Law, Saveetha Institute of Medical and Technical Science (SIMATS), Chennai, Tamilnadu, India.

Dr. Sreeya B, Associate Professor, Saveetha school of law, Saveetha Institute of Medical and Technical Science (SIMATS), Chennai, Tamilnadu, India.(Email: sreeyab.ss1@ saveetha.com) anyone else's input. People who change employments can assess, regardless of whether they really confront enhancements or decreases in essential occupation attributes. Consider the type of working environment you want. Think about the nature of the work, the hours, location, job security, rate of pay, benefits, size, type of organization and so on. Identify the opportunities you want. These might incorporate progressing to a more senior position or creating particular aptitudes. On the recent survey conducted The following report represents the findings from the SHRM Employee Job Satisfaction and Engagement Survey of 600 U.S. employees, conducted in November-December 2015.we examined the job perceptions and preferences of young people aged 14 to 19 years at the interface between education and training and the world of work.

\section{OBJECTIVES}

- To understand about the preference of job.

- To analyze the association between the hesitation towards night shift job and occupation of the respondent.

- To find the difference between the preference of job and the gender

- To identify the agreeability towards factors of job preference and the age of the respondents.

\section{LITERATURE REVIEW}

Charles N. Weaver (2017) explored about employment inclinations of professional and hands on specialists. The creator takes note of a pattern in enthusiasm among specialists on different parts of word related stratification, referring to the examination of qualities connected to different parts of work by cubicle and manual laborers as a repeating topic. Contrasts in states of mind and conduct are centered around. Research finds that desk specialists are more worried about inborn qualities which exude from the work itself, for example, an occupation be viewed as vital and gives a sentiment of achievement, while hands on laborers are more worried about the "outward" parts of an occupation, for example, its going with monetary prizes or limited time openings. FRANCIS GREEN (2017) examined what job satisfaction looks like for you; you know what you value and which values you want satisfied by your work, you have determined yours. The best place to start is by having a career discussion with your manager, mentor or coach. Stephan G.H. MEYERDING (2016) examines the possibility of non-straight connections between employment qualities and occupation fulfillment. The connections between trademark esteems and work and life fulfillment are dissected and the aftereffects of the three gatherings are

Published By:

Blue Eyes Intelligence Engineering

\& Sciences Publication 
thought about. Moreover, bosses' reasonable treatment of the general public overall strongly affects work fulfillment. Alzira Duarte (2016) has determined the present master dissertation was a result of the interest in investigate about which kind of determinant characteristics will influence the choice of first job by students and recent graduated students, especially the ones that belong to the Informatics and technology area and socio-economic/ socio-humanistic area. This empirical research was just applied to a national context. Neetu Jain (2015) analysed and understand the employer branding has in this way developed as a basic administration hone utilized by the association to make its picture as alluring manager according to imminent representatives. The outcomes introduced in this paper toss light on the apparent significance of business marking among the planned representatives by means of examination of different marking factors decided for the investigation. MARISA ANN CANNATA, ROBERTO PENALOZA (2015) investigates the accompanying inquiries: How do educator capabilities and attributes change crosswise over school composes? What amount of decision do educators feel they have about where to work? How do educator inclinations for where to work vary by school compose? Our discoveries recommend that sanction teachers do have distinctive inclinations for where to work contrasted with customary state funded teachers, however understanding these distinctions requires investigating contrasts among sorts of contract schools as well. PANEL MEHMET PEKKAYA Since various criteria exist, fitting profession determination issue can be thought as a multi criteria basic leadership issue. The point of this examination is to demonstrate that vocation choice can be completed by means of strategies and to look at requesting consequences of these techniques. In this investigation, a study is controlled to a college understudy. In application, eight callings are relatively positioned by means of some techniques. DUNCAN GALLIC, ALAN FEELS TEAR, FRANCIS GREEN (2012) found that the esteem that representatives append to the inherent parts of work is vital for regardless of whether work quality issues ought to have a focal place on the social plan. Despite what might be expected, it demonstrates that inherent activity inclinations ascended over the period. The development in significance of inherent introductions is related with rising levels of training and parental consolation in instruction, the change of individuals' occupations regarding ability, learning openings and worker inclusion and higher wages and security. KATHERINE MCGRAW, JENNIE S. POOP, BRUCE L. DIXON, AND DORIES J. NEWTON (2012) identifies factors that influence agricultural economics professionals' job choice between academic and government employment. They likewise concurred that having a positive workplace, great compensation, family time, sufficient assets, and expert and social collaboration were vital occupation characteristics. scholarly and government horticultural financial matters experts, binomial probit, work decision, work inclinations, sex. CHRISTIAN GRUND (2011) states that worker i0nitiated Job Changes Many past investigations endeavor to find work inclinations by specifically asking people. Representatives who quit their activity and locate another one, contrast the two employments with deference with eight occupation qualities: kind of work, pay, odds of advancement, remaining burden, driving time, work hour directions, incidental advantages and security against loss of employment For reasons unknown, pay and kind of work are most imperative for representatives in this sense.

\section{METHODOLOGY}

For the purpose of this study descriptive research is used to portray accurately the public opinion on problem solving skills. Convenient sampling method is used to collect the samples. 1850 samples - sample size. Independent variables are gender, educational qualification, age. Dependent variables are Problem solving process, choice of overcoming the problem, mean of level of agreeability towards Problem solving skills. Independent sample t test, chi square and ANOVA are the research tools used in this research.

\section{ANALYSIS AND DISCUSSION}

Null Hypothesis (Ho): There is no significant association between the hesitation towards night shift job and occupation of the respondents

Alternate Hypothesis (H1): There is significant association between the hesitation towards night shift job and occupation of the respondents

Table 1: Cross tabulation - People hesitates to prefer Night shift job and Occupation of respondents

\begin{tabular}{|l|l|r|r|r|}
\hline \multirow{2}{*}{} & \multicolumn{2}{|c|}{$\begin{array}{c}\text { People hesitates to prefer Night } \\
\text { shift job }\end{array}$} & \multirow{2}{*}{ Total } \\
\cline { 3 - 4 } \multicolumn{2}{|c|}{} & Yes & No & \\
\hline \multirow{3}{*}{ Occupation } & Business & 297 & 136 & 433 \\
\cline { 2 - 5 } & Private & 338 & 524 & 862 \\
\cline { 2 - 5 } & Govermment & 118 & 437 & 555 \\
\hline Total & 753 & 1097 & 1850 \\
\hline
\end{tabular}

Table 2: Chi square test - People hesitates to prefer Night shift job and Occupation of respondents

\begin{tabular}{|l|c|c|c|}
\hline \multicolumn{4}{|c|}{ Chi-Square Tests } \\
\hline & Value & df & $\begin{array}{c}\text { Asymp. Sig. } \\
\text { (2-sided) }\end{array}$ \\
\hline Pearson Chi-Square & $227.243^{\mathrm{s}}$ & 2 & .000 \\
\hline
\end{tabular}

Using chi square test, it was found that $\mathrm{p}$ value is less than 0.05 , which shows that null hypothesis is rejected. Therefore, there is significant association between the hesitation towards night shift job and occupation of the respondents. It shows that occupation creates an impact on the hesitation of night shift jobs

Null Hypothesis (Ho): There is no significant difference between the preference of job and gender

Alternate Hypothesis (H1): There is significant difference between the preference of job and gender 


Table 3: Preference of job and the gender
\begin{tabular}{|l|r|r|r|r|}
\hline Gender & \multicolumn{1}{|c|}{ N } & \multicolumn{1}{c|}{ Mean } & $\begin{array}{c}\text { Std. } \\
\text { Deviation }\end{array}$ & $\begin{array}{c}\text { Std. Error } \\
\text { Mean }\end{array}$ \\
\hline Male & 816 & 1.54 & .499 & .017 \\
\hline Female & 1034 & 1.37 & .483 & .015 \\
\hline
\end{tabular}

Table 4: Independent sample t Test- Preference of job and the gender

\begin{tabular}{|l|l|l|l|}
\hline & t & df & Sig. (2-tailed) \\
\hline $\begin{array}{l}\text { First opinion regarding job } \\
\text { preference }\end{array}$ & 2.023 & 1848 & 0.001 \\
\hline
\end{tabular}

Using Independent sample $t$ test, it was found that $p$ value is less than 0.05 , which shows that null hypothesis is rejected. Therefore, there is significant difference between preference of job and the gender. It shows that male and female have different opinion regarding preference of job in their day to day life.

Null Hypothesis (Ho): There is no significant difference in the mean scores of level of agreeability towards factors of job preferences among the age group.

Alternate Hypothesis (H1): There is significant difference in the mean scores of level of agreeability towards factors of job preferences among the age group.

Table 5: ANOVA - Level of agreeability towards factors of job preferences and age group

\begin{tabular}{|l|l|r|r|r|r|r|}
\hline \multicolumn{2}{|l|}{} & \multicolumn{1}{|c|}{$\begin{array}{c}\text { Sum of } \\
\text { Squares }\end{array}$} & df & Mean Square & F & Sig. \\
\hline \multirow{2}{*}{$\begin{array}{l}\text { Passion play a key role } \\
\text { in job selection }\end{array}$} & $\begin{array}{l}\text { Between } \\
\text { Groups }\end{array}$ & 89.846 & 3 & 29.949 & 22.498 & .000 \\
\cline { 2 - 7 } & Within Groups & 2457.330 & 1846 & 1.331 & & \\
\hline & Total & 2547.176 & 1849 & & & \\
\hline \multirow{4}{*}{ Improvement in status } & $\begin{array}{l}\text { Between } \\
\text { Groups }\end{array}$ & 52.378 & 3 & 17.459 & 28.332 & .000 \\
\cline { 2 - 8 } & Within Groups & 1137.568 & 1846 & .616 & & \\
\cline { 2 - 8 } & Total & 1189.946 & 1849 & & & \\
\hline \multirow{3}{*}{ Challenging job } & $\begin{array}{l}\text { Between } \\
\text { Groups }\end{array}$ & 69.408 & 3 & 23.136 & 25.919 & .000 \\
\cline { 2 - 8 } & Within Groups & 1647.768 & 1846 & .893 & & \\
\cline { 2 - 8 } & Total & 1717.176 & 1849 & & & \\
\hline \multirow{2}{*}{$\begin{array}{l}\text { Extra-curicular } \\
\text { activities in workplace }\end{array}$} & $\begin{array}{l}\text { Between } \\
\text { Groups }\end{array}$ & 111.367 & 3 & 37.122 & 42.164 & .000 \\
\cline { 2 - 8 } & Within Groups & 1625.282 & 1846 & .880 & & \\
\cline { 2 - 7 } & Total & 1736.649 & 1849 & & & \\
\hline
\end{tabular}

Using ANOVA it was analysed whether the level of agreeability towards factors of job preferences among the age group. Since the $p$ value of all the reasons are lesser than 0.05 , it was found that there is significant difference in the mean scores of level of agreeability towards Problem solving skills among the educational qualification groups.

\section{CONCLUSION}

This study explored that most of the youth prefer job which have job satisfaction, job security, salary or pay and mostly they prefer job through their passion and interest .The findings of this study suggests that Anyway what young men and young ladies say they need from their employments is more comparative than various and if youngsters have more data about the subtle elements of work, pay and ways of life they are less worried by sexual orientation generalizations. It in this manner appears to be likely that sexual orientation isolation can be lessened by drawing in youngsters with data, counsel and direction which centers around the substances of occupation undertakings, pay and way of life. Along these lines, there should be a superior method for motioning to youngsters the advantages of specific vocation decisions. They also had a realistic sense of the salary to expect upon entering the workforce. It is concluded that job preferences will include all factors such as job security, passion or interest salary and work environment etc.

\section{REFERENCES}

1. Browne, Beverly A. 1997. "Gender and Preferences for Job Attributes: A Cross Cultural Comparison." Sex Roles 37 (1-2): 61-71.

2. Cannata, Marisa Ann, and Roberto Penaloza. 2012 "Who Are Charter School Teachers? Comparing Teacher Characteristics, Job Choices, and Job Preferences." Education Policy Analysis Archives 20 (0): 29.

3. "EmeraldInsight." n.d. Accessed November 9, 2018a https://www.emeraldinsight.com/doi/abs/10.1108/JMD09-2013-0106? journalCode $=\mathrm{jm}$.

4. ---. n.d. Accessed November 9, 2018b. https://www.emeraldinsight.com/doi/abs/10.1108/17538 351111172608.

5. "Kailing Shen." n.d. Accessed November 9, 2018. http://www.nber.org/people/teddyhoney.

6. McGraw, Katherine, Jennie S. Popp, Bruce L. Dixon, and Doris J. Newton. 2012. "Factors Influencing Job Choice among Agricultural Economics Professionals." Journal of Applied Agricultural Economics 44 (02): 251 65.

7. Meyerding, Stephan G. H. 2016. "Job Satisfaction and Preferences Regarding Job Charactereistics of Vocationals and Master Craftsman Scholars and Horticulture Students in Germany." Review of Agricultural and Applied Economics 19 (01): 30-49.

8. "[No Title]." n.d. Accessed November 9, 2018a https://ageconsearch.umn.edu/bitstream/254149/2/RAAE _1_2016_Meyerding.pdf.

9. ---. n.d. Accessed November 9, 2018b http://citeseerx.ist.psu.edu/viewdoc/download?doi=10.1. $1.418 .8395 \&$ rep $=$ rep $1 \&$ type $=$ pdf.

10. --. n.d. Accessed November 9, $2018 \mathrm{c}$ http://zeynepaycan.net/doc/j20.pdf.

11. Rothe, Peggie, Anna?liisa Lindholm, Ari Hyvönen, and Suvi Nenonen. 2012. "Work Environment Preferences Does Age Make a Difference?" Facilities 30 (1/2): 78-95.

12. "SAGE Journals: Your Gateway to World-Class Journal Research." n.d. SAGE Journals. Accessed November 9, 2018a.

http://journals.sagepub.com/doi/abs/10.1177/095001701 2451633.

13. ---. n.d. SAGE Journals. Accessed November 9, 2018b. http://journals.sagepub.com/doi/abs/10.2466/pr0.1987.61 .3 .983 .

14. "ScienceDirect." n.d. Accessed November 9, 2018. https://www.sciencedirect.com/science/article/pii/S22125 67115004864.

15. Taylor, Dorceta. 2007. "Employment Preferences and Salary Expectations of Students in Science and Engineering." Bioscience 57 (2): 175-85.

16. "Website." n.d. Accessed November 9, 2018a https://journals.aom.org/doi/abs/10.5465/255637?journal Code $=$ amj.

17. ---. n.d. Accessed November 9, 2018b https://repositories.iscteiul.pt/bitstream/10071/13705/1/Disserta\%C3\%A7\%C3\% A3o\%20de\%20Mestrado\%20$\% 20$ Marta\%20Almeida.pdf.

18. --- n.d. Accessed November 9, 2018c http://www.educationforhealth.net/article.asp?issn=1357 6283 ; year $=2008 ;$ volume $=21 ;$ issue $=3 ;$ spage $=164 ;$ epage $=1$ $64 ;$ aulast=Modipa 
PERSONAL PREFERENCE IN CHOOSING A JOB

19. ---. n.d. Accessed November 9, $2018 \mathrm{~d}$. https://www.researchgate.net/publication/236651468_Jo b_Selection_Preferences_Of_Business_Students.

20. ---. n.d. Accessed November 9, $2018 \mathrm{e}$ http://psycnet.apa.org/record/1968-16189-001. 